\title{
脳卒中片麻痺患者に対する把握力調整能力評価トレーニングデバイスの 有用性検証
}

\author{
森田良 文*·安藤 晃 平*. 野 村 正 和* \\ 戸 嶋 和 也**・田丸 司**
}

Verification of Usefulness of Testing/Training Device of Adjustability for Grasping Force on Hemiplegic Patients after Stroke

Yoshifumi Morita*, Kohei Ando*, Masakazu NomurA*, Kazuya ToshimA** and Tsukasa TAMARU**

\begin{abstract}
Adjustability for grasping force (AGF), which is one of motor function of fingers, is an ability to grasp an object with appropriate force. Since a person with a disable hand can not adjust grasping force, he/she grasps an object with extra force or can not grasp it due to lack of grasping force. In our previous study, we developed a training and testing device of the AGF, which is called iWakka. In this paper the usefulness of training and testing with iWakka was confirmed by applying $\mathrm{CI}+\mathrm{i}$ therapy to ten hemiplegic patients after stroke. The AGF of all patients was improved after training with $\mathrm{CI}+\mathrm{i}$ therapy. CI+i therapy was developed by the fourth and fifth authors by adding the training task with iWakka to CI (Constraint Induced Movement) therapy.
\end{abstract}

Key Words: rehabilitation, training, testing, device, adjustability for grasping force

\section{1.はじめに}

日常生活において人間は手指でものをつかんでもち上げた り，箸やボールペンを使ったりしている。このようにものを 手指で操作する場合，ものの重さや表面の材質などの特性に 応じて把握力を調整している。このような把握を精密把握と 呼び, この精密把握動作には巧緻性, すなわち器用さが必要 であるとされる。この精密把握動作に関してはさまざまな観 点から研究が行なわれてきた ${ }^{1) \sim 4)}$. 一方, 脳卒中片麻痺患者 に対して, 文献 5)では 2 週間の CI (Constraint movement therapy) 療法 ${ }^{6)}$ を適用して, 文献 7) ではロボットを用いて 把握動作を含む上肢機能のトレーニングおよび評価に関する 報告がある，それぞれに上肢機能の回復を認めているが，精 密把握動作については述べられていない。これまで臨床現場 において精密把握動作を評価したり，トレーニングしたりす るデバイスは存在しない.

第 1 著者らは, 精密把握動作に必要な巧緻性として, 筋収

* 名古屋工業大学大学院工学研究科 名古屋市昭和区御器所町

** (医) 偕行会偕行会リハビリテーション病院 弥富市神戸 5-20

* Graduate School of Engineering, Nagoya Institute of Technology, Gokiso-cho, Showa-ku, Nagoya

** Kaikokai Rehabilitation Hospital, 5-20 Kando, Yatomi (Received May 31, 2018)

(Revised October 9, 2018)
縮を適切にコントロールして把握力を調整する能力（以降, 把握力調整能力）を考え，この把握力調整能力の低下具合に 対して定量的評価，およびトレーニングを提供するのが，第 1 著者らが開発したiWakka である ${ }^{8) ~ 10) . ~ i W a k k a ~ に よ り, ~}$ 手指でものを扱う際の把握力の測定を提供し, さらに使用者 に課題を与えることで, 把握力調整能力の定量的評価と併せ て把握力調整能力の回復のためのトレーニングを提供する.

現在, iWakka は複数の医療現場に導入され, さまざまな 目的で臨床研究が行なわれている，そこでは，単なる評価デ バイスとしてだけでなく, 利用方法を変えることでトレーニ ングデバイスとしても有用なことが明らかになっている．評 価デバイスとしては, 把握力調整能力のテストバッテリーと するための基礎研究として, iWakka がどんな種類の誤差を 生じ，それがどの程度生じるのかといったiWakka の測定誤 差の特性を明らかにしている ${ }^{11), 12)}$. また, iWakka を使っ て健常者の把握力調整能力をさまざまな観点から検討した報 告がある ${ }^{13) ~ 16)}$. 一方, トレーニングデバイスとしては, 復 職に求められる業務遂行能力の向上を目指し, iWakkaをリ ワークプログラムに導入した報告がある ${ }^{17)}$.

第 4 , 第 5 著者の所属機関である偕行会リハビリテーショ ン病院では, 回復期の脳卒中片麻痺患者 (以降, 脳卒中患者) に対する上肢運動機能の回復トレーニングとして CI 療法を 導入している.さらに最近では，このCI 療法にiWakka によ るトレーニングを組み込んだ CI+i 療法を導入し始めている. 
本論文の目的は, $\mathrm{CI}+\mathrm{i}$ 療法を脳卒中患者に適用して iWakka の有用性を検証することにある。そのために，iWakkaによ る評価課題および定量的評価方法の見直しを行なった。それ を用いた $\mathrm{CI}+\mathrm{i}$ 療法のトレーニング効果を検証することで, iWakka によるトレーニングの有用性と, CI+i 療法における 経過観察にiWakka を導入することで，iWakka による評価 の有用性を検証する。ただし，iWakkaのみによるトレーニ ング効果の検証は行なわれていないことに注意されたい. 本 論文で行なわれるトレーニング効果の検証は $\mathrm{CI}+\mathrm{i}$ 療法によ るものであるが，これを iWakkaによる有用性として表記す ることに注意されたい，また，従来の iWakkaによる評価課 題では, 把握力の目標值としてステップ状の時間変化を用い ていたが, 脳卒中患者にとっては難しいことからランプ状の 時間変化に変更した。これに伴い, 定量的評価をランプ状の 時間変化の区間だけとした。

\section{2. トレーニング評価デバイス iWakka}

把握力調整能力とは, 筋収縮を適切にコントロールして把 握力を調整する能力と考える. 開発した把握力調整能力評価 トレーニングデバイス iWakkaは, 把握力計測デバイス, 把 握力調整能力の評価課題, およびその定量的評価方法からな る. 把握力計測デバイスは, 把握デバイス Wakka, コント ロールボックス，ノート PC からなる、コントロールボック スとノート PC は USB ケーブルで接続され, USB ポート からコントロールボックスに電源供給が行なわれる. Fig. 1 にWakka を把持するようすとiWakkaのモニ夕画面を示す. Wakka を手指で把握すると, 板ばねが変形して Wakka の 幅が変化する．この変化する幅のことを変形量と呼ぶ．これ により，弾性体の特性をWakka で再現することができる. Wakkaの変形量と反発力との関係は線形性を有する。ばね定 数は $4.82 \times 10^{2} \mathrm{~N} / \mathrm{m}$ である.これはWakkaを $49.2 \mathrm{~g}$ の力 で押すと $1 \mathrm{~mm}$ の変形量が生じることを意味する. Wakkaの 高さは $80 \mathrm{~mm}$, 外径は $65 \mathrm{~mm}$, 重量は $0.112 \mathrm{~kg}$ である. サ

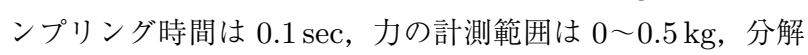
能は $1.6 \mathrm{~g}$ である．iWakkaの詳細については文献 8) を参照 にされたい.

把握力計測デバイスを用いて把握力調整能力を定量的に評 価するために, 一定值とランプ状の変化が組み合わさった時間 的に変化する把握力の目標值（以降，目標把握力）に沿って, 被験者が把握力を調整するといった評価課題を考案した．目 標把握力を Fig. 2 に示す。それをモ二夕画面に写し, 把握力 調整能力を定量的に評価するソフトがiWakka Viewer 2017 である. 目標把握力はあらかじめモ二夕画面に表示され, 把握 力の現在の值が時間経過とともにモ二夕画面の左側から右側 に動くように表示される．目標把握力の最大值である $0.4 \mathrm{~kg}$ で Wakka を把握すると, Wakka に約 $8 \mathrm{~mm}$ の変形量が生じ る. 把握力と目標把握力との誤差の平均值 (以降, 平均誤差) を計算することで，把握力を意のままに調整できるかを定量 的に評価している。この数值が小さいほど把握力調整能力が

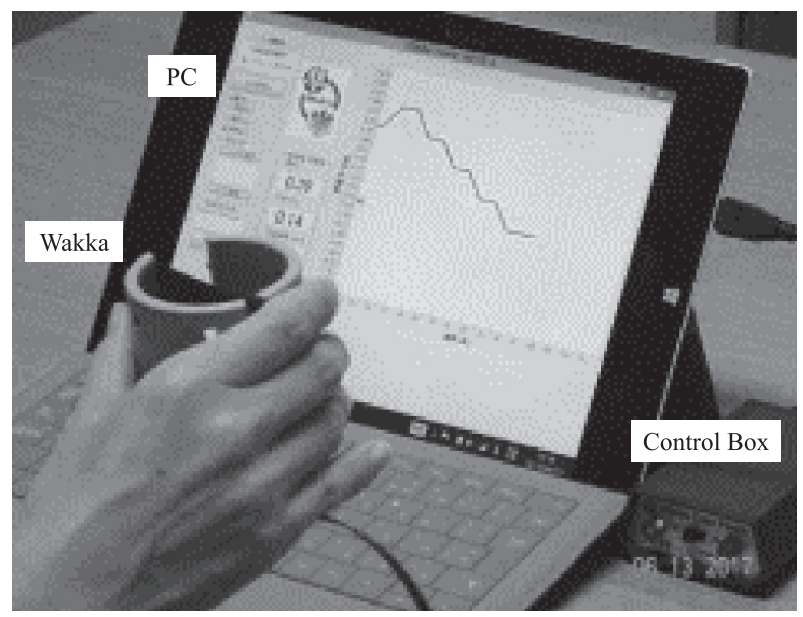

Fig. 1 Testing and training device of adjustability of grasping force

高いものとする。iWakka Viewer 2017 には，ユーザー管理 機能, 保存データの表示・比較機能, COM ポート自動接続 機能など, 医療現場のニーズに基づいた改良がなされている.

\section{3. 定量的評価指標}

Fig. 2 に示す目標把握力に沿って被験者が把握力を調整す るといった評価課題に対して，定量的な評価法を考える。こ の課題を達成するためには，等尺性筋活動（Isometric contraction), 求心性筋活動 (Concentric contraction), および 遠心性筋活動（Eccentric contraction）が必要となる．等尺 性筋活動により一定の把握力で把持すること, 求心性筋活動 により iWakka を把握しながら iWakka が閉じる方向に手指 を動かすこと，すなわち把握力が大きくなるように手指を動 かすこと, 遠心性筋活動により iWakka が開く方向に手指を 動かすこと, すなわち把握力が小さくなるように手指を動か すことが可能となる。 そこで, 把握動作における等尺性筋活 動, 求心性筋活動, および遠心性筋活動のそれぞれにおける 調整能力を個別に定量的に評価する.ささらに, 求心性筋活動 と遠心性筋活動においては, 目標把握力の大きさに応じて個 別に評価する。目標把握力と評価区間を Fig. 2 に示す．等尺 性筋活動の調整能力の評価区間を IC, 求心性筋活動を 10 個 に分けて目標把握力の小さいほうから順に評価区間を $\mathrm{CC} 1$ CC10, 遠心性筋活動を 10 個に分けて目標把握力の大きいほ うから順に評価区間を EC1〜 EC10 と示す。

把握力調整能力の定量的評価指標として, 各評価区間にお ける把握力の平均誤差を用い, 以下の計算式から求める.

$$
A G F_{(*)}=\frac{1}{T} \sum_{k=1}^{N}\left|f_{d}(k)-f(k)\right| \quad[\mathrm{g}]
$$

$(*)$ は評価区間を示し,$f(k)$ は把握力の測定值, $f_{d}(k)$ は目 標把握力である， $T$ は評価区間の時間であり, IC では $5 \mathrm{sec}$, それ以外では $3 \mathrm{sec}, N$ は評価区間のデー夕数であり, IC で は 50 個，それ以外では 30 個である．等尺性筋活動の調整能 


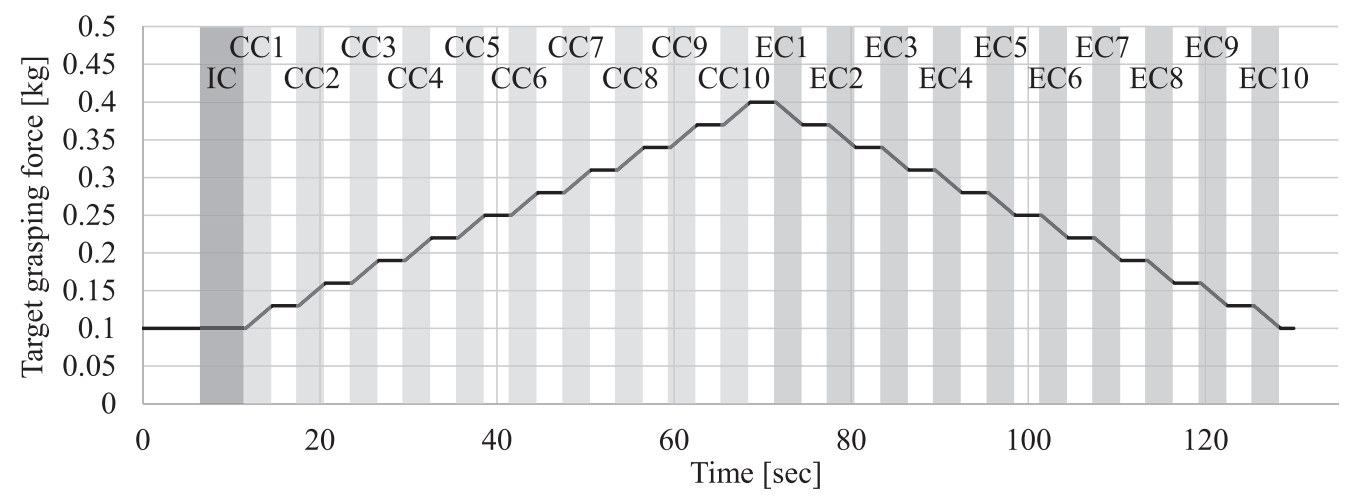

Fig. 2 Target grasping force and evaluation sections

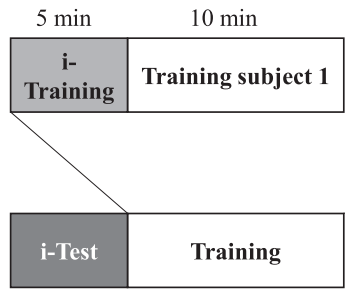

1st day

\begin{tabular}{|c|c|}
\hline \multicolumn{1}{c|}{$5 \mathrm{~min}$} & $10 \mathrm{~min}$ \\
\hline $\begin{array}{c}\text { i- } \\
\text { Training }\end{array}$ & Training subject 2 \\
\hline
\end{tabular}

\begin{tabular}{|c|c|}
\hline $5 \mathrm{~min}$ & $10 \mathrm{~min}$ \\
\hline $\begin{array}{c}\text { i- } \\
\text { Training }\end{array}$ & Training subject 3 \\
\hline
\end{tabular}

\begin{tabular}{|c|c|}
\hline $\begin{array}{c}\mid c \\
\text { i- } \\
\text { Training }\end{array}$ & Training subject 4 \\
\hline
\end{tabular}

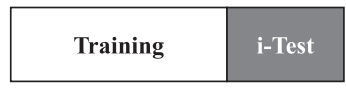

18th day

Fig. 3 Training protocol of CI+i therapy

力の評価指標を $A G F_{I C}$, 求心性筋活動の調整能力の評価指 標を $A G F_{C C i}(i=1, \cdots, 10)$, 遠心性筋活動の調整能力の評 価指標を $A G F_{E C i}(i=1, \cdots, 10)$ とする。これらの 21 区間 の評価指標の值をグラフに示すことにより，筋活動の種類と 把握力調整能力の関係性が明らかとなり, 患者一人一人に適 したリハビリメニューの作成に有益な情報となると考えられ る.一例を後出の Fig. 8 に示す. 詳細については後述する. また， 21 個の評価区間のすべてにおける平均誤差も評価指標 の 1 つとし，これを $A G F_{\text {Total }}$ とする。よって，評価指標の 個数は 22 個とする. なお, 目標把握力の最大值の $0.4 \mathrm{~kg}$, 計

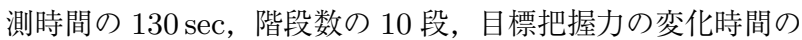
$3 \mathrm{sec}$ などは，5つの医療機関によるモニタから得られた臨床 的な知見に基づいて決めた.

\section{4. 脳卒中患者における検証実験}

本研究では, 脳卒中患者を対象に, $\mathrm{CI}+\mathrm{i}$ 療法によるトレー ニングの効果の検証から，iWakkaのトレーニングデバイス としての有用性を，日々のトレーニングの効果の経過観察を 通して, iWakka の評価デバイスとしての有用性を検証する.

そこで，偕行会リハビリテーション病院に入院中の脳卒中 患者 10 名を対象に $\mathrm{CI}+\mathrm{i}$ 療法を適用した。すべての対象者 に対して事前に調査内容を説明し，書面による同意を得た。 通常の CI 療法は 1 日 60 分，18 日間の集中トレーニングで あり，患者は麻疩上肢を使った 4 つの課題を行なっている. 一方で，一つ一つの課題の時間を 15 分から 10 分に短縮し, 各課題の前に 5 分間のiWakkaによるトレーニングを導入し た $\mathrm{CI}+\mathrm{i}$ 療法の適用を試みている。 $\mathrm{CI}+\mathrm{i}$ 療法のプロトコール
を Fig. 3 に示す。図中では, iWakka による評価を i-Test, iWakka によるトレーニングを i-Training と記す。iWakka による評価の実施タイミングは，初日のみ $\mathrm{CI}+\mathrm{i}$ 療法による トレーニングの前，それ以降は毎日， $\mathrm{CI}+\mathrm{i}$ 療法によるトレー ニングの後に実施した.

iWakka によるトレーニングも評価も, 患者が行なう遂行課 題は同じで，Fig. 2 に示す目標把握力の追従課題である。た だし，iWakka による評価では，追従課題を 1 回のみ行ない， 把握力の時系列デー夕を保存し，解析などに用いた。iWakka によるトレーニングでは， 5 分間に追従課題を 3,4 回行なっ た．iWakkaによるトレーニングも評価も座位にて行ない，被 験者はテーブルの上で Wakka を把握し，テーブルからもち 上げることはしない，測定姿位は基本的には文献 11) と同じ とした。具体的には，対象者の座る位置と姿勢を一定にする ために，背もたれは使用せず，両脚は肩幅程度に開かれた状 態で，膝関節は 90 度屈曲位とした。iWakka は対象者の身体 から $0.25 \mathrm{~m}$ の位置にし，モ二夕は対象者の体から $0.5 \mathrm{~m}$ の位 置に置くこととした。しかしながら，被験者の麻痺の程度に よっては，腕の姿勢を調整するなどすることで，無理のない ようにした。

\section{5. 実験結果および有用性検証}

\section{1 実験結果と有用性}

実験結果の一例から, iWakka がトレーニングデバイスと評 価デバイスとして有用であることを確認する．被験者 4 の 1 日 目と 18 日目の iWakkaによる評価における把握力の時間変化 をそれぞれ Fig.4(a)(b) に示す。1 日目については Fig. 4(a) 
Table 1 Information of patients (STEF: simple test for evaluating hand function, FMA: Fugl-Meyer assessment)

\begin{tabular}{ccccccccccc}
\hline Sub No. & Age & Sex & Paralysis side & Post-stroke duration [day] & \multicolumn{2}{c}{$A G F_{\text {Total }}[\mathrm{g}]$} & \multicolumn{2}{c}{ STEF } & \multicolumn{2}{c}{ FMA } \\
& & & & & Pre & Post & Pre & Post & Pre & Post \\
\hline 1 & 80 & $\mathrm{M}$ & $\mathrm{L}$ & 119 & 74.8 & 13.0 & 3 & 0 & 21 & 21 \\
2 & 79 & $\mathrm{~F}$ & $\mathrm{R}$ & 106 & 34.7 & 24.2 & 0 & 3 & 35 & 41 \\
3 & 29 & $\mathrm{M}$ & $\mathrm{R}$ & 48 & 7.2 & 6.1 & 61 & 75 & 57 & 62 \\
4 & 36 & $\mathrm{M}$ & $\mathrm{L}$ & 174 & 25.8 & 13.3 & 0 & 0 & 20 & 32 \\
5 & 62 & $\mathrm{M}$ & $\mathrm{R}$ & 30 & 17.3 & 9.7 & 14 & 37 & 53 & 62 \\
6 & 66 & $\mathrm{M}$ & $\mathrm{R}$ & 106 & 51.5 & 16.2 & 0 & 3 & 28 & 48 \\
7 & 43 & $\mathrm{M}$ & $\mathrm{R}$ & 129 & 25.1 & 19.5 & 2 & 21 & 47 & 51 \\
8 & 50 & $\mathrm{M}$ & $\mathrm{R}$ & 210 & 35.5 & 20.3 & 21 & 46 & 23 & 26 \\
9 & 74 & $\mathrm{~F}$ & $\mathrm{R}$ & 75 & 53.3 & 26.8 & 17 & 42 & 39 & 40 \\
10 & 72 & $\mathrm{M}$ & $\mathrm{L}$ & 96 & 42.0 & 21.1 & 27 & 56 & 43 & 51 \\
\hline Mean & 59.1 & & & 109.3 & 36.7 & 17.0 & 14.5 & 28.3 & 36.6 & 43.4 \\
SD & 17.5 & & & 51.2 & 18.6 & 6.2 & 18.1 & 25.4 & 12.7 & 13.3 \\
\hline
\end{tabular}

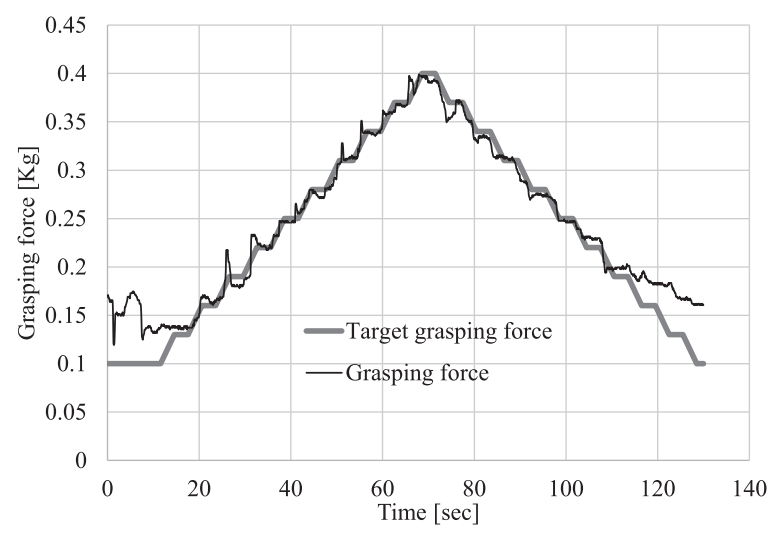

(a) 1st day

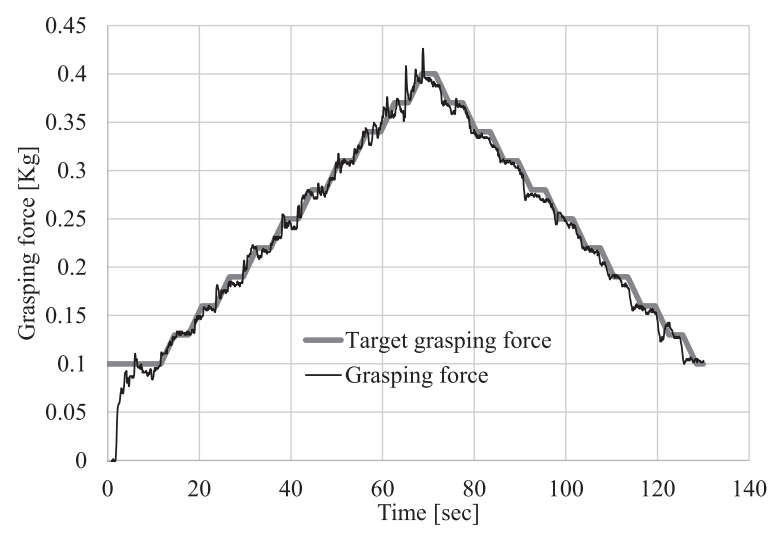

(b) 18th day

Fig. 4 Time history of grasping force before and after training with CI+i therapy on Patient 4

から以下のことがわかる. 0〜 $10 \mathrm{sec}$ あたりにおいて把握力が 目標把握力から離れていることから， $0.1 \mathrm{~kg}$ のような小さい 把握力での調整が上手くできていないことがわかる。求心性 筋活動における時刻 $26 \mathrm{sec} ， 32 \mathrm{sec} ， 50 \mathrm{sec} ， 56 \mathrm{sec} に$ におて 把握力が目標把握力から大きく逸脱しており，それらの時刻 は目標把握力がランプ状から一定值に切り替わったときであ ることから，把握力を徐々に強めていく過程から把握力を一 定值に止めようとする際に過大な把握力を発揮してしまうこ とがわかる，時刻 $17 \mathrm{sec} よ り 以$ 前や，遠心性筋活動における

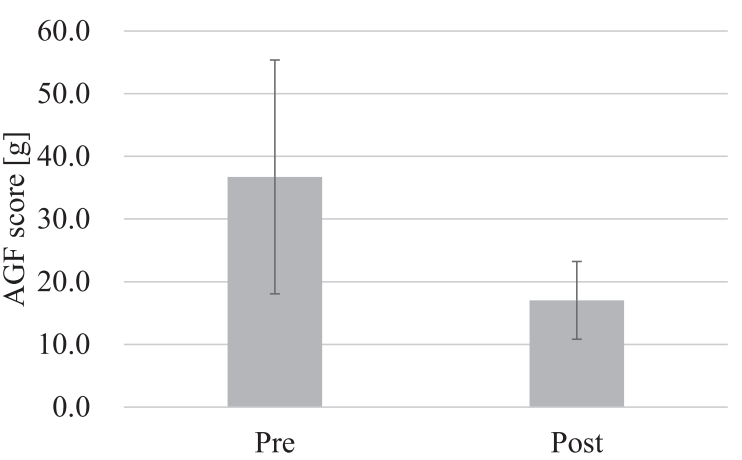

Fig. 5 AGF index before and after training with $\mathrm{CI}+\mathrm{i}$ therapy

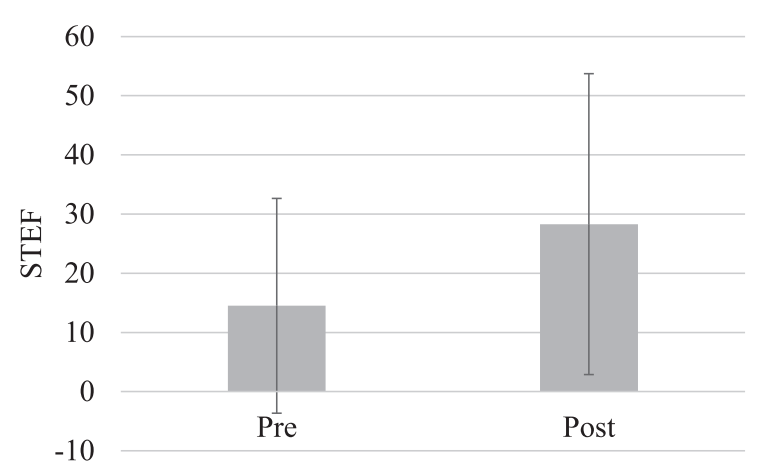

Fig. 6 STEF score before and after training with CI+i therapy

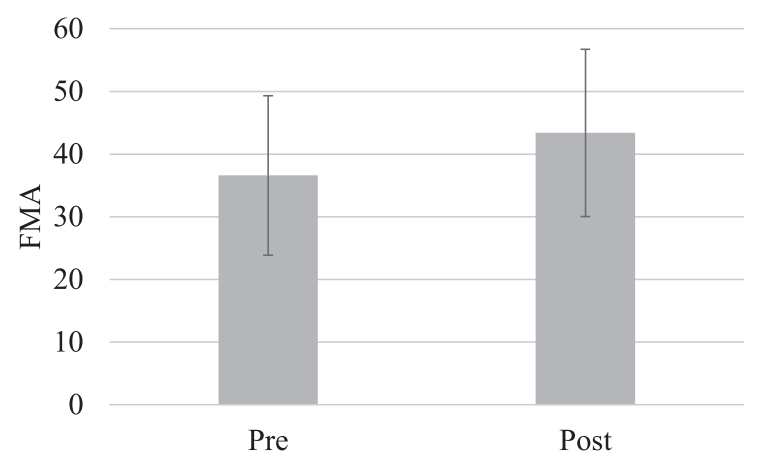

Fig. 7 FMA score before and after training with $\mathrm{CI}+\mathrm{i}$ therapy 


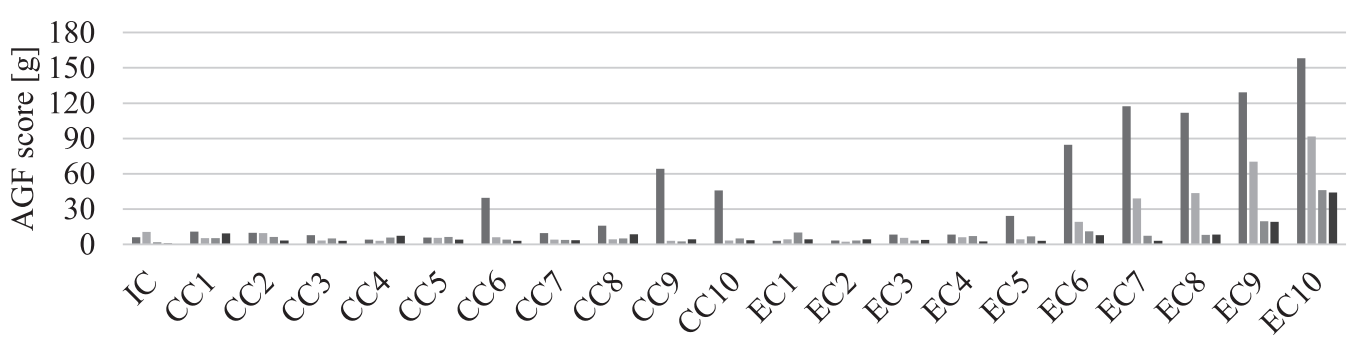

(a) Display range of AGF score of $0-180 \mathrm{~g}$

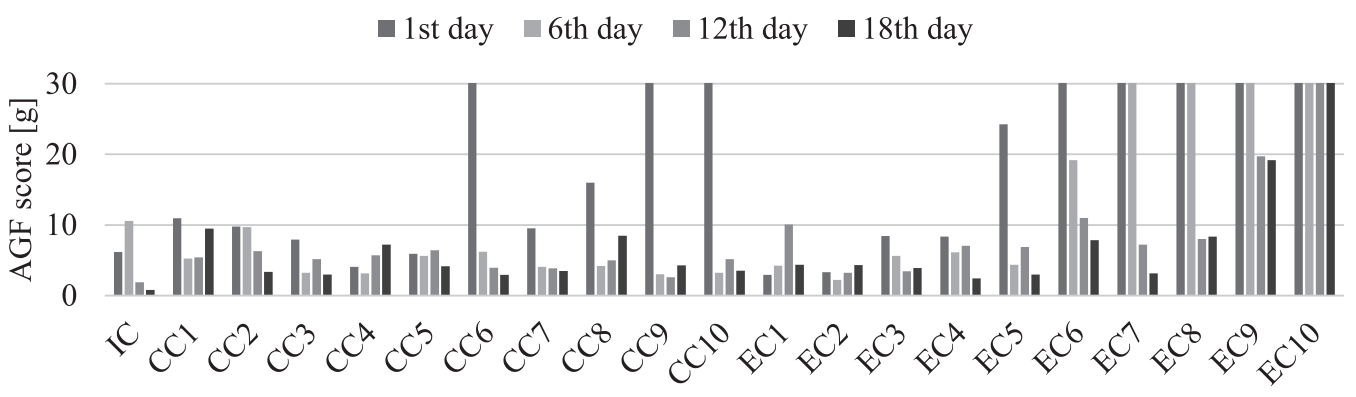

(b) Display range of AGF score of $0-30 \mathrm{~g}$

Fig. 8 AGF indices of Patient 1

時刻 $104 \mathrm{sec}$ 以降では，把握力が目標把握力からずれている ことから，小さい把握力での調整が上手くできていないこと がわかる。一方, 18 日目については Fig.4(b) から以下のこ

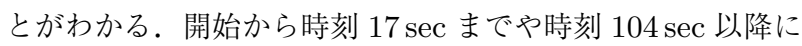
おいて，小さい把握力での調整ができるようになっているこ とがわかる．グラフを用いた把握力の時間変化の観察から手 指の把握力調整能力を評価することができる.さらに， 1 日 目と比較することで，手指の把握力調整能力のトレーニング 効果が確認できる.

以上により, iWakka がトレーニングと評価の 2 つの機能と して有用であることがわかる。そこで，10 名の被験者のデー タを用いて，トレーニングデバイスと評価デバイスとしての iWakka の有用性を以下にて検証する。

\section{2 トレーニングデバイスとしての有用性}

$\mathrm{CI}+\mathrm{i}$ 療法による 18 日間のトレーニングの前後における麻 痺側の把握力調整能力 $A G F_{T o t a l}$, 簡易上肢機能検査 STEF (STEF: Simple Test for Evaluating Hand Function)，およ び上肢機能についての FMA（Fugl-Meyer Assessment）の結 果を Table 1 に示す. 10 名の平均値と標準偏差を Fig. 5 Fig. 7 に示す. STEF とは, 10 種のサブテストによる上肢 機能障害に対するテストである。テスト方法は検査台上で形 状や重さ，材質の異なる 10 種類のパーツを把持・移動・離 す一連の動作を左右の手を個別に行ない，それぞれにかかっ た時間をポイントに置き換えて評価する，満点は 100 点であ る ${ }^{18)}$. FMA とは, 脳血管障害患者の機能障害の評価におけ る総合的身体機能評価法である.上肢機能についての満点は 66 点である.

$\mathrm{CI}+\mathrm{i}$ 療法によるトレーニングによって, Fig. 5 から，把握
力調整能力が改善されていることがわかる，ちなみに，事前 調査から, 若年健常者 $(22.5 \pm 1.3$ 歳, $\mathrm{n}=19$ (男性 18 名, 女 性 1 名)）の $A G F_{\text {Total }}$ は利き手が $3.66 \pm 0.86 \mathrm{~g}$, 非利き手が $3.70 \pm 1.01 \mathrm{~g}$ であり, 高齢健常者（70.9 3.8 歳， $\mathrm{n}=36$ (男性 27 名, 女性 9 名)）の $A G F_{\text {Total }}$ は利き手が $8.5 \pm 3.6 \mathrm{~g}$, 非利 き手が $7.7 \pm 3.2 \mathrm{~g}$ である ${ }^{12), 19) .}$

トレーニングの前後における $A G F_{\text {Total }}$ を対応ありの $\mathrm{t}$ 検 定を行なった結果，有意確率が $p=0.0071(p<0.05)$ であ ることから有意差が認められた. STEF についても，対応あ りのWilcoxonの符号付順位検定を行なった結果，有意確率 が $p=0.0051(p<0.05)$ であることから有意差が認められ た. FMAについても, 対応ありの $\mathrm{t}$ 検定を行なった結果, 有 意確率が $p=0.0054(p<0.05)$ であることから有意差が認 められた．以上， CI+i 療法によるトレーニングによって上肢 の機能の改善が認められ，iWakkaのトレーニングデバイス としての有用性が確認できた。

\section{3 評価デバイスとしての有用性}

被験者 1 と被験者 4 の 1 日目，6 日目， 12 日目，および 18 日目の各評価指標を Fig. 8 と Fig. 9 に示す. (a) のグラフ の縦軸を拡大したグラフが (b) である. Fig. 8(b) と Fig. 9(b) の最大目盛りは同じであるが，Fig. 8(a) と Fig. 9(a)の最大 目盛りが異なることに注意されたい.

Fig. 8 から被験者 1 について以下が観察される。1 日目には 求心性筋活動における $A G F_{C C 6}, A G F_{C C 9}$, および $A G F_{C C 10}$ が大きかったが，6 日目以降は小さくなり，それ以降も小さ いことがわかる. 求心性筋活動と遠心性筋活動を比べると, 遠心性筋活動における AGF の值が大きいことがわかる．特 に目標把握力が小さい区間において顕著である。1 日目には 
$\square$ 1st day $\quad 6$ th day $\quad \square 12$ th day $\quad \square 18$ th day

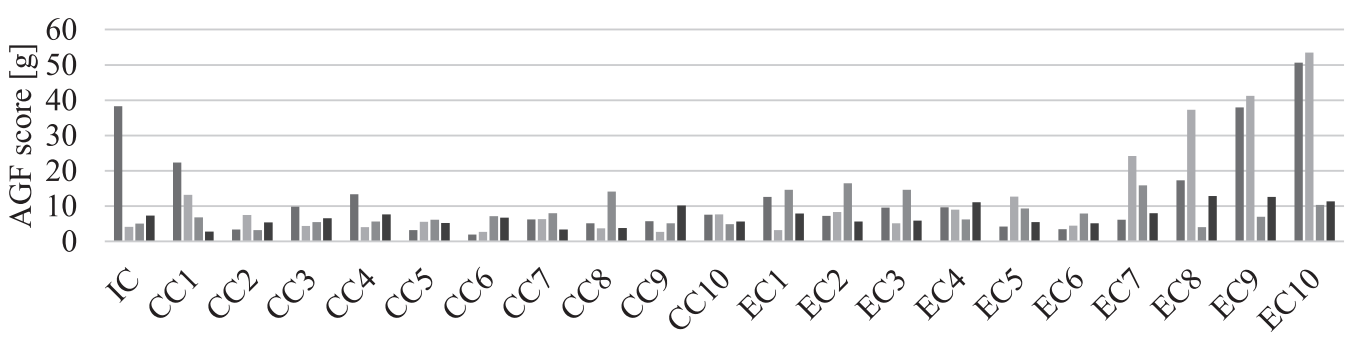

(a) Display range of AGF score of $0-60 \mathrm{~g}$

$\square$ 1st day $\quad 6$ th day $\square 12$ th day $\square 18$ th day

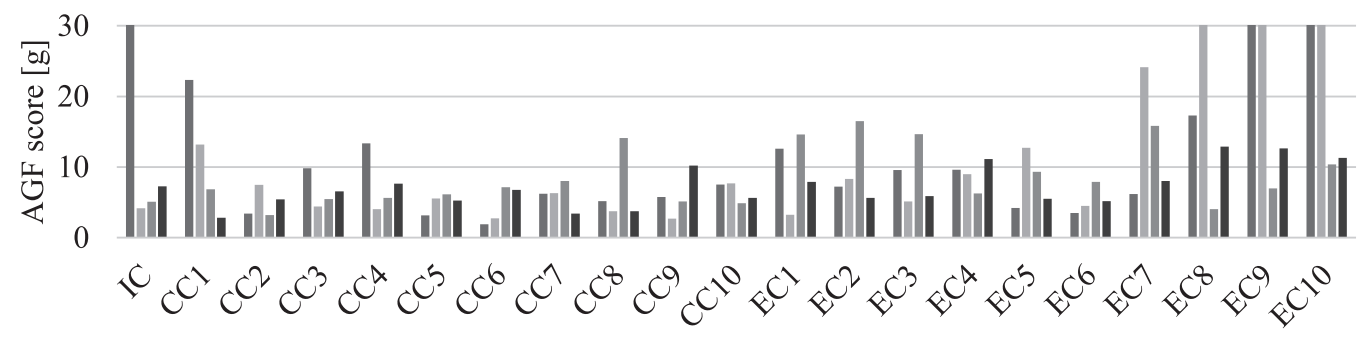

(b) Display range of AGF score of $0-30 \mathrm{~g}$

Fig. 9 AGF indices of Patient 4

$A G F_{E C 6} \sim A G F_{E C 10}$ の值が大きいが，トレーニングを継続 することで小さくなることがわかる.

Fig. 9 から被験者 4 について以下が観察される. 被験者 1 に 比べると AGF の值が全体的に小さいことがわかる．被験者 1 と同様に, 求心性筋活動と遠心性筋活動を比べると, 遠心性筋 活動における $\mathrm{AGF}$ の值が大きいことがわかる．特に目標把 握力が小さい区間において顕著である. $A G F_{I C}$ や $A G F_{C C 1}$ も大きい。しかしながら，これらもトレーニングを継続する ことで小さくなることがわかる。これより，18 日間のトレー ニングにより把握力調整能力が改善されたことがグラフから 読み取ることができる。

脳卒中患者は正常な筋活動が苦手であり, 上肢の場合, 屈曲 パターンの共同運動に支配されるため，手指関節を伸展させ ること，すなわち把握力を弱めることは苦手とされる，この ような特徵が結果のグラフから確認できた. Fig. 8 と Fig. 9 のような評価指標の棒グラフは，たとえば電気刺激療法を用 いた治療パターンの選定などに有用である。具体的には，求 心性筋活動区間の AGF の值が遠心性筋活動区間のそれに比 べて大きい場合は浅指屈筋と深指屈筋に，その逆の場合は総 指伸筋に電気刺激を与えることを目安にしている。このよう に主動筋の運動に関する感覚フィードバックを強化すること で，被験者は力加減の程度を認識しやすくなり，それが運動 学習を促進させると考えられる，以上により，iWakkaの評 価デバイスとしての有用性が確認できた.

\section{6. おわりに}

$\mathrm{CI}+\mathrm{i}$ 療法によるトレーニングを 10 名の脳卒中片麻痺患者 に適用した実験結果から, iWakka のトレーニングデバイス
としての有用性，および評価デバイスとしての有用性を明ら かにした.

現在, CI 療法と CI+i 療法の比較について並行群間比較試 験を実施中である。これにより，iWakkaによるトレーニン グの併用に有効性があることを示す予定である．また， CI+i 療法によるトレーニングの結果，患者の中には箸の使い方が 上手になった人もいた．箸を使うときの手の動きと，Wakka を握るときの手の動きは異なるが，把握運動を通して，物品 を扱う際に必要な運動パターンを学習した結果と考えており, 今後解明に向けた臨床研究を予定している。ささらに，今後， $\mathrm{CI}+\mathrm{i}$ 療法に電気刺激療法を組み合わせて治療効果を高める ために, AGF の值と電気刺激の筋選定および刺激強度との関 係性の解明，それに基づく治療効果の高いトレーニングプロ トコールの策定を行なう予定である.

本臨床研究は偕行会リハビリテーション病院の倫理審査委 員会の承認を得て実施されたものである.

謝辞 本研究の被験者実験にご協力いただいた偕行会リハ ビリテーション病院の患者さんとスタッフの皆さんに謝意を 表する。

\section{参 考 文 献}

1）長尾竜郎：手指動作の研究（第 1 報），日本リハビリテーショ ン医学会誌, 8-1, 3/12 (1971)

2）川合，木下，生田：物体重量の変化と摘み力の関係からみた精 密把握運動の摘み力制御について, 体力科学, 43-4, 247/258 (1994)

3）川合, 津田, 木下, 生田, 橋詰, 村瀬, 山本 : 老齢化が精密把握 時の摘み力適応調節に及ぼす影響，体力科学，46-5, 501/512 (1997)

4）木下, 青木, 津田, 奥, 橋川：小物体の精密把握持ち上げ運動 
に関わる脳機能局在の検討，バイオメカニズム, 16, 101/113 (2002)

5) S.L. Wolf, C.J. Winstein, J.P. Miller, E. Taub, G. Uswatte, D. Morris, C. Giuliani, K.E. Light and D. Nichols-Larsen: Effect of constraint-induced movement therapy on upper extremity function 3 to 9 months after stroke: The EXCITE randomized clinical trial, The Journal of the American Medical Association, 296-17, 2095/2104 (2006)

6) Constraint-Induced Movement therapy, https://www.uab.edu/citherapy/

7) R. Buschfort, J. Brocke, A. Hess, C. Werner, A. Waldner and S. Hesse: Arm studio to intensify the upper limb rehabilitation after stroke: Concept, acceptance, utilization and preliminary clinical results, Journal of Rehabilitation Medicine, 42-2, 310/314 (2010)

8）山崎, 北山, 中嶋, 佐藤, 森田, 鵜飼, 桜井, 久保田, 矢崎, 小森，田口：把握動作に拈ける感覚運動統合機能の定量的評価 のための計測デバイスの開発，日本福祉工学会誌，16-1, 20/25 (2014)

9）森田, 中嶋, 佐藤，矢崎：把握力調整能力の定量的評価システ 厶, 日本福祉工学会誌, 18-2, 5/10 (2016)

10）森田，矢崎，桜井：みんなによるみんなのためのリハビリ支援 機器の開発のためには，第 32 回ライフサポート学会大会，第 16 回日本生活支援工学会大会, 日本機械学会福祉工学シンポ ジウム 2016(LIFE2016) 論文集，196/198 (2016)

11）金野，佐藤，矢崎，森田，柴垣，秋月：把持力調整能力評価法 の測定誤差の検討, 理学療法科学, 32-1, 117/121 (2017)

12) T. Kaneno, A. Sato, K. Akizuki, A. Yamaguchi, K. Yasaki and Y. Morita: Assessing the adjustability of grasping force using the iWakka in elderly individuals, Journal of Physical Therapy Science, 29-12, 2215/2219 (2017)

13）佐藤，金野，森田，山口，矢崎：健常高齢者の微細な把握力調 整能力は非利き手の方が優れている, 第 51 回日本作業療法学 術大会抄録集，PP-2E07 (2017)

14）佐藤，金野，矢崎：健常成人における筋収縮様式の違いによ る把持力調整能力の比較, 目白大学健康科学研究, 10, 15/21 (2017)

15）時田，金野，佐藤，矢崎，森田：把握動作の調整 · 維持 · 産出 における心理物理的特性の検討，日本基礎心理学会第 36 回大 会, 2-49 (2017)

16) 矢吹, 秋月, 大橋: 学習者の課題遂行成績に応じた可変性バン ド幅の有効性についての検討, 第 26 回埼玉県理学療法学会, 11 (2018)

17）武井，高橋，矢崎：リワークプログラムでの iWakka を用い た取り組み，第 51 回日本作業療法学術大会抄録集，PH-1B03 (2017)

18) https://www.sakaimed.co.jp/measurement_analysis/ function-test/stef/

19）安藤，柴垣，森田，矢崎，佐藤，金野：把握力調整能力の定量的 評価デバイスにおける測定誤差の検討, 日本機械学会ロボティ クス・メカトロニクス講演会'17 講演論文集, 2P2-Q07(1)-(2) (2017)
1

$$
\text { [著 者 紹 介] }
$$

森田良文 (正会員)

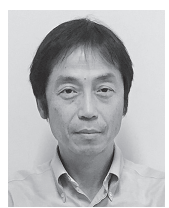

1989 年名古屋工業大学大学院工学研究科博士前 期課程修了。同年 (株) 日本電装 (現在，(株) デ ンソー）に入社. 91 年岐阜工業高等専門学校電子 制御工学科助手. 2000 年名古屋工業大学電気情報 工学科講師. 現在, 同大学大学院工学研究科教授. 博士 (工学)。ロボットの運動制御, 人間機械協調 系の支援制御，リハビリ支援ロボットなどの研究 に従事. 電気学会, 日本機械学会, 日本ロボット 学会，日本生活支援工学会，IEEE などの会員，

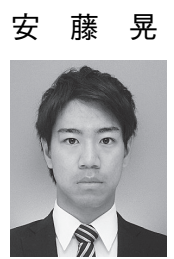

2017 年名古屋工業大学工学部電気電子工学科 卒業. 2017 年名古屋工業大学大学院工学研究科電 気 ·機械工学専攻博士前期課程在学中. 現在, 手 指機能のリハビリテーションデバイスの研究開発 に従事. 電気学会の学生員.

\section{野 村 正 和}

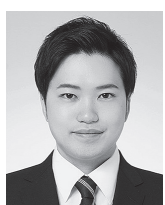

2018 年名古屋工業大学工学部電気電子工学科 卒業. 2018 年名古屋工業大学大学院工学研究科電 気 ·機械工学専攻博士前期課程在学中. 現在, 手 指機能のリハビリテーションデバイスの研究開発 に従事.

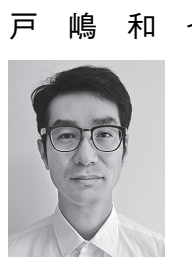

2005 年 (学) 佑愛学園愛知医療学院（現在, 愛 知医療学院短期大学) 卒業. 現在, (医) 偕行会偕 行会リハビリテーション病院作業療法士. 日本作 業療法士協会. 日本臨床神経生理学会など会員.

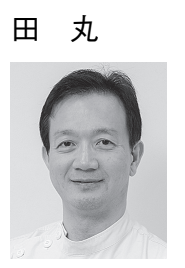

司

1989 年奈良県立医科大学卒業. 同大学神経内 科，同リハビリテーション部などを経て，2004 年 (医) 偕行会入職, 2012 年より偕行会リハビリテー ション病院院長. 日本神経学会専門医·指導医, 日 本リハビリテーション学会専門医・指導医, 日本 臨床神経生理学会会員など. 